\title{
Religion and Peacebuilding in Sub-Saharan
}

Africa

Lado Tonlieu Ludovic, S. J.

\section{INTRODUCTION}

Three religious systems dominate the religious landscape in Sub-Saharan Africa today: African traditional religions, Christianity, and Islam. Religion remains a significant component of social life on the African continent; recent projections suggest that this importance will continue for the next four decades. ${ }^{1}$ According to a 2016 survey conducted by the Pew Research Center, "The share of Christians worldwide who live in Sub-Saharan Africa is expected to increase dramatically between 2015 and 2060 , from 26 percent to 42 percent, due to high fertility in the region. Sub-Saharan Africa is also expected to become home to a growing share of the world's Muslims. By 2060, 27 percent of the global Muslim population is projected to be living in the region, up from 16 percent in 2015."2

L. T. Ludovic, S. J. (凶)

Centre d'Étude et de Formation pour le Développement (CEFOD), N'Djamena, Chad e-mail: directeurcefod@gmail.com

(C) The Author(s) 2021

T. McNamee and M. Muyangwa (eds.),

The State of Peacebuilding in Africa, https://doi.org/10.1007/978-3-030-46636-7_4 
But, clear-cut statistics can be misleading when it comes to dynamics of religious identity in Africa, partly because of the complexity of religious practice. In daily practice, religion is perceived and lived primarily as a problem-solving tool. Many believers expect religion to solve personal and social problems such as finding a spouse, bearing a child, curing an illness, finding a job, fighting witchcraft, obtaining a visa, etc. This is especially pronounced in the context of the crisis of the social responsibility of the state. ${ }^{3}$ The complexities of the religious landscape paired with the importance of religions in the lives of Africans mean that "to ignore religion, as a matter of obvious political and even economic importance, threatens the credibility of academic investigations." 4 This insight obviously applies to the domain of peacebuilding in Africa as peace, justice, and reconciliation feature prominently among the religious expectations of African believers.

The role of religion in peacebuilding in Africa has to be located within the wider framework of the role of religion in the public space in Africa more generally. Indeed, religion and public policy "intertwine because both claim to give authoritative answers to important questions about how people should live." 5 In a critical appraisal of earlier theories of secularization, José Casanova has argued that although the fusion of politics and religion is no longer an option in modern societies, at least in the West, the social differentiation of religion and politics is not incompatible with the public role of religion. ${ }^{6}$ In spite of processes of secularization, religious voices are not absent from public debates-especially those that directly challenge their core beliefs and practices. To begin with, "religion in Africa was never relegated, even superficially, to a space outside politics and current events, or to benign places of private worship. Rather, because of the history of religion and religious transformation in Africa, religion has always been perceived, by a majority of Africans, as having the power to radically change social life and history." 7 It is, therefore, no surprise that people in Africa turn to religion for resources to prevent conflicts or to restore peace.

The past 30 years have been marked by major developments that have determined the role of religion in Africa's public sphere. These include the continent's tilt toward democracy, the decline of the social responsibility of the state particularly following the implementation of the Structural Adjustment Programs of the 1980s and 1990s, civil wars, and threats from a variety of non-state armed groups, including terrorist organizations. Given these developments, non-state actors, including religious organizations, have thrived, and some have taken up the challenge of peacebuilding. 
The first section of this chapter reviews some of the major developments in the field of religious peacebuilding in Africa in a context of crisis-ridden democratization processes; the second section looks at the case studies of Côte d'Ivoire and the Central African Republic (CAR), and explores some key issues and lessons learned related to religious peacebuilding; the third and final section identifies three issues that require the attention of policymakers.

\section{The Past 30 Years: An Overview of Major Developments in Religious Peacebuilding in Africa}

Whereas in Western academic circles there are debates about what some have described as the "return" of religion in the public space, in Africa the reality is that religion has never left the public space, in spite of the rhetoric of the "secular" state. ${ }^{8}$ Not only is religion present in the public space, it is eager to make its voice heard in policymaking. Besides their active involvement in the fields of relief services, education, health, human rights, and civic education, religious organizations in Africa have been involved in the three dimensions of peacebuilding-preventing violence, managing conflict, and transforming conflicts. ${ }^{9}$ Thomas Banchoff rightly speaks of the "underappreciated" contribution of religious communities to peacemaking: "Less visible, but no less significant, is the peaceful engagement of religious communities in contemporary world affairs. ... But it is nonviolent. Less likely to make the newspapers, it has far-reaching, if underappreciated, impact." 10

\section{Religious Diplomacy}

In a number of significant cases, religious diplomacy has succeeded where state actors and international organizations had failed to bring back peace in communities torn by conflicts. The outstanding peacemaking success of the Catholic lay movement of Sant'Egidio in Mozambique is one of the best illustrations of this commitment to peace of religious organizations. Thanks to their quiet and discrete diplomacy, consisting of several rounds of talks between warring factions, they managed to secure a peace agreement in October 1992 which ended decades of civil war between FRELIMO and RENAMO. ${ }^{11}$ 
Over the past 30 years, religious leaders in a number of African countries have been called upon to act as mediators, especially in times of political transition and conflicts. For example, religious leaders were solicited in the early 1990s to preside over sovereign national conferences in countries such as Benin, Republic of Congo, and the Democratic Republic of the Congo, and on the whole, they were quite effective in facilitating peaceful transitions from one-party systems to political pluralism. ${ }^{12}$ This was a tremendous contribution to peace and stability. Even in countries, such as Zambia, where there was no national conference, churches played a critical role to ensure a relatively peaceful transition to multiparty politics in the early 1990s. In the late 1980s and early 1990s, they exerted public pressure on Kenneth Kaunda's regime to return to a pluralistic political system. ${ }^{13}$ Religious leaders have also been called upon to head national truth and reconciliation commissions. Archbishop Desmond Tutu was in charge of the first commission of this kind in Africa, leading the reconciliation process in post-Apartheid South Africa. Since then a number of clerics have been appointed to such commissions in other countries, including Togo and Côte d'Ivoire.

\section{Islamic Social and Humanitarian Services}

Recent decades have also witnessed the growing visibility of Islamic social and humanitarian services in a field previously dominated by Christian and secular social and relief services. One of the major successful Muslim peacebuilding actors in Africa is the Wajir Peace and Development Committee (WPDC), (based in the Wajir district of north-eastern Kenya), which incorporates Muslim traditional mechanisms and values in its conflict resolution initiatives. Some of its achievements include the establishment of a Joint Committee of Clans to monitor tensions and prevent violent conflict in the Wajir district; the increased acknowledgment of the contribution of women to peacemaking in their communities; a change in attitude among local police chiefs; and the incorporation of peace education in schools. ${ }^{14}$ Besides Muslim peacebuilding actors, there is also a growing recognition of the contribution of women, and religious women in particular, to peacebuilding in Africa. There are a number of efforts underway to make these contributions more visible. ${ }^{15}$ For example, the Sudanese Women's Voice for Peace (SWVP), formed in March 1994, contributed to peacebuilding in Sudan through peace 
education programs and campaigns meant to raise awareness and prevent violence at the grassroots level. ${ }^{16}$

\section{Inter-faith Peacebuilding Initiatives and Education for Peace}

Another major evolution in this field in recent decades is the multiplication of inter-faith peacebuilding initiatives and the progressive acknowledgment at the international level of their contribution to peacebuilding. In Sub-Saharan Africa, inter-faith organizations exist at the local, national, and international levels. Some of the most notable at the continental level are the African Council of Religious Leaders (ACRL), - Religions for Peace, the Inter-Faith Action for Peace in Africa (IFAPA), the Programme for Christian-Muslim Relations in Africa (PROCMURA), and the InterReligious Council of Sierra Leone (IRCSL). Multi-faith associations in peacebuilding have the potential to neutralize attempts to divide communities along religious lines. ${ }^{17}$ They also go a long way to help "change the negative perceptions and suspicions that exist between the various religious communities," and to engage in "dialogical action," meaning "organized actions to transform the social structures of injustice within society." 18 The Coalition for Peace in Africa (COPA), based in Kenya, is one such organization. Its activities include advocacy, inter-faith dialogue, education, intermediation based on traditional Islamic justice, and conflict resolution mechanism of Suluh (the Arabic word for reconciliation), and traditional African methods of conflict management and resolution involving elders, chiefs, youth, and women.

\section{Case Studies, Key Issues, and Lessons Learned}

Since inter-faith initiatives are the most prominent tool of religious peacebuilding in Sub-Saharan Africa, this section probes two case studies: Côte d'Ivoire and the Central African Republic. Over the past two decades, Côte d'Ivoire and the Central African Republic have witnessed political crises involving the use of religion in contradictory ways: to justify violence and to build peace. These cases are a good illustration of what some scholars have termed the "ambivalence of religion." 19 In Côte d'Ivoire, the timely intervention of religious leaders prevented the transformation of a political conflict into a religious one; in the Central African Republic they have been less successful. 


\section{Côte d'Ivoive}

Côte d'Ivoire, the economic and political locomotive of francophone West Africa, is still trying to recover from the political crisis that consumed the country throughout much of the 2000s. This crisis was essentially fueled by a power struggle tapping into identity politics, which almost took a religious turn. Most of the political and economic life of Côte d'Ivoire is concentrated in the southern part of the country, particularly in Abidjan, the economic capital, leaving the northern part of the country with fewer opportunities. This situation makes Northerners feel marginalized. Also, in popular perceptions, the South is mostly associated with Christianity whereas the North is linked with Islam, in spite of the fact a substantial number of Northerners have migrated to the South in search for economic opportunities. For this reason, the North/South divide is also presented as a Muslim/Christian divide. But, in spite of these underlying perceptions, Muslims and Christians mostly coexist peacefully.

The most recent general population census took place in 2014 and provides some data on the religious demography of Côte d'Ivoire's 22.7 million people (per a 2016 estimate) (Table 4.1). ${ }^{20}$ What these statistics show is that although Muslims are the majority population in the country, more than half of them are immigrants from neighboring countries. This reality has sustained the idea of "the Muslim as a stranger" in popular perceptions in Côte d'Ivoire". However, given the intricacies of migration patterns in Côte d'Ivoire, distinguishing an Ivorian from a nonIvorian, a distinction that is at the heart of nationalistic politics in Côte d'Ivoire, is not obvious. Indeed, a war of succession with nationalistic overtones followed the death of President Félix Houphouët-Boigny, the

Table 4.1 Religious distribution of the population of Côte d'Ivoire

\begin{tabular}{lccc}
\hline Religions & Ivoirians & Non-Ivoirians & Percentage/Population \\
\hline All Christians & 39.1 & 17.7 & 33.9 \\
Muslims & 33.7 & 72.7 & $\mathbf{4 2 . 9}$ \\
Animists (Traditional religions) & 4.4 & 0.9 & 3.6 \\
Other religions & 0.6 & 0.2 & 0.5 \\
Without religion & 22.2 & 8.5 & 19.1 \\
& 100.0 & 100.0 & 100.0 \\
\hline
\end{tabular}

Source Institute National de la Statistique, Recensement Général de la Population et de l'Habitat 2014 (Côte d'Ivoire, 2014), http://www.ins.ci/n/documents/RGPH2014_expo_dg.pdf 
first president of independent Côte d'Ivoire, in 1993. The conflict exacerbated ideological and social cleavages, culminating in an armed rebellion in 2002. The rebellion split the country into two, with the North, associated in collective representations with Muslims, on one side, and the South, linked with Christianity, on the other. Until then, followers of Islam, Christianity, and African traditional religions had, mostly coexisted peacefully in Côte d'Ivoire. But, from 1995 onwards, there were repeated attempts by successive ruling "Christian" presidents to exclude Alassane Ouattara, a Muslim linked to the North and labeled as a non-native Ivorian, from presidential contests. These attempts were the formalization of the policy of "Ivoirianness" (ivoirité) launched by Henri Konan Bédié upon taking office as President after the death of Houphouët-Boigny. The policy of Ivorianness was the embodiment of identity politics meant to distinguish the "true" Ivorian from the non-Ivorian in a country with a large proportion of immigrants (about 25 percent).

The 2000 elections were contested principally by President Gbagbo and Ouattara. During the violent confrontations between the pro-Gbagbo and the pro-Ouattara factions in the aftermath of the elections, a mosque in the city of Abidjan was looted and burned down by youth associated with Gbagbo's party. In retaliation, a group of young people linked with Ouattara's party burned a Christian church in another part of the city. Following this, more Muslim dignitaries suspected to be close to Ouattara's camp and to the rebels in the North were assassinated in the South. In the space of three months, three imams were assassinated. ${ }^{21}$ The risk of the conflict taking a sharp religious turn was real. Fortunately, most Muslim leaders never called for retaliation against Christians. Their only public complaint was that they were being targeted because of political feuds. Their restraint played a major role in preventing the conflict from degenerating into further inter-religious violence.

It is in a similar context conducive to religious conflict that the National Forum of Religious Denominations (Forum National des Confessions Religieuses) was launched in 1995. Indeed, religious leaders were concerned about the growing threat of the instrumentalization of religion for political purposes and wanted to prevent the transformation of a political crisis into a religious conflict. The Forum attracted around 20 different religious denominations including Catholics, Protestants, Evangelicals, Muslims, adherents of African traditional religions, Bahaï faith followers, and Harrists. Since its creation, the Forum has operated as a structure of religious mediation both between political opponents and 
between religious denominations in an effort to promote social cohesion. Its main tools of social intervention include joint declarations to warn the faithful against the political manipulation of religion (especially in the aftermath of the destruction of mosques and other acts of violence targeting religious denominations), joint prayer sessions, and political mediation, as well as training and sensitization programs for the faithful. All these interventions seek to prevent conflict and promote social cohesion.

However, the Forum has faced a number of challenges. As a result of religious differences, some Protestants and Evangelicals refused to join the Forum, arguing that some of its members' religions are witcheraft or diabolical. The Forum has also been plagued by governance issues. For example, the founding text stipulated that the presidency is to rotate among religious denominations, but the first president of the Forum elected in 1995 ended up abolishing the rule thus causing the demission of some of its founding members.

\section{The Central African Republic}

The Central African Republic has been plagued by conflict since independence in 1960. It is also one of the poorest countries in the world.

Table 4.2 shows that Christians constitute about 70 percent of the overall population whereas Muslims make up only 10 percent. Most Christians live in the South whereas the North is associated with Islam.

Table 4.2 The religious distribution of the CAR population in 2003

\begin{tabular}{lc}
\hline Description & $\begin{array}{c}\text { Overall } \\
(\%)\end{array}$ \\
\hline Total & 100 \\
Catholics & 28.9 \\
Protestants & 51.4 \\
Muslims & 10.1 \\
Other religions & 4.5 \\
No religion & 3.6 \\
Unspecified & 1.5 \\
\hline
\end{tabular}

Source Bureau Central du Recensement, Direction Générale de la Statistique, des Études Économiques et Sociales, Ministère de l'Économie, du Plan et de la Coopération Internationale, Résultats du Recensement Général de la Population et de l'Habitation Decembre 2003 (Central African Republic, 2003), https://ireda. ceped.org/inventaire/ressources/caf-2003-rec-o_rca_en_chiffres.pdf 
The North is poorer than the South and has become the breeding ground for rebel groups that pose a major threat to the stability of the country.

The 2015 elections aimed to end the sectarian violence that exploded in 2013. The conflict centers on the violence between two militias: the Séléka, ${ }^{22}$ linked with Islam, and the anti-Balaka, ${ }^{23}$ associated with Christianity. Séléka appeared on the political scene of the Central African Republic in 2012 as a loose coalition of dissident political and rebel groups. The group lacked any clear political agenda-except their common objective to overthrow the then-head of state François Bozizé. Séléka finally succeeded in forcing him out of power in March 2013, and their leader Michel Djotodia took over as the new ruler of the country. Though the group was not predicated on religious affiliation, the rebel groups forming Séléka drew their membership from the country's marginalized North, which is predominantly Muslim. As a result, most of the combatants who overthrew Bozizé's regime were Muslims. Many explicitly targeted Christians and their properties in acts of violence and extortion, exacerbating communal tensions.

The anti-Balaka faction is a loosely structured set of self-defense groups that emerged in 2009 , before the current crisis, to counter extortion and insecurity generated by organized armed robbery on the roads. Initially, it had neither a political nor a religious connotation. The group simply embodied a limited community response to a situation of insecurity that the weak state security apparatus was unable to address effectively. People felt they had to take responsibility for their own security. Once these groups emerged in a context of a weak and unstable state such as the Central African Republic, they were hard to control.

Following the coup d'état by the Séléka rebels in 2013, the antiBalaka emerged once again as a grassroots response to the ensuing chaos. Muslims became the main targets for acts of revenge by anti-Balaka, who accused them of being accomplices to the crimes of the retreating Séléka. Since then anti-Balaka groups have terrorized Muslim communities suspected of cooperation with the dismantled Séléka, and thousands of Muslims have fled to neighboring countries.

Having acknowledged the religious tenor of the conflict, it is important to underline the fact that neither Séléka nor anti-Balaka qualify as a religious group from a sociological point of view. Neither of these groups 
is institutionally related to a major religious organization. Nor do the groups appear to be pursuing a clear religious agenda, as do terrorist groups such as Al-Qaeda, Boko Haram, or al-Shabaab. Furthermore, neither Séléka nor anti-Balaka has the open support of any major religious group inside or outside of the Central African Republic. And, because Christianity and Islam are not a monolithic reality in the Central African Republic, it is just as difficult to link Séléka with a particular Muslim group as it is to connect anti-Balaka with a particular Christian denomination. However, there are some suspicions among the population that some factions of anti-Balaka are being controlled and manipulated for political purposes by allies of the overthrown president, François Bozizé.

When the factional violence erupted in 2013 in the CAR, Cardinal Nzapalainga, the Archbishop of Bangui; Imam Oumar Kobine Layama, the President of the Islamic Community of CAR (CICA); and Reverend Pastor Nicolas Guerekoyame-Gbangou, the President of the Alliance of Evangelicals of CAR, came together to denounce attempts by the main instigators to transform a military and political conflict into an inter-religious conflict. As factional killings intensified, they became ambassadors for peace at the national and international levels. Their efforts led to the creation of the Plateforme des Confessions Religieuses de Centrafrique (PCRC) whose motto is, "For an interreligious approach to peace and social cohesion." ${ }^{24}$ In June 2016, the PCRC met to draft its foundational documents, including a charter, rules and procedures, as well as a strategic plan. Besides a board of directors, the governing structure of the PCRC comprises a permanent secretariat, various commissions, and regional branches. The three main denominations represented in the PCRC are Catholicism, Protestantism, and Islam. In addition to managing a website and running radio programs to educate the population on peacebuilding, they also intend to establish regional offices for outreach programs and grassroots engagement. The PCRC has become the backbone of the peace process in the Central African Republic. This is an especially critical role given that rebuilding the institutional infrastructure of the country will take years.

It remains to be seen how the PCRC will handle denominational differences within the organization and associated structures. This could also become a weakness that hinders sustainability. The PCRC is probably among the youngest national inter-religious platforms on the continent, 
but it is also one of the most structured organizations, underpinned by a clear strategic plan. Its sustainability will depend on the ability of its leaders to maintain a united front around common objectives. But as donors pour in money, it might ignite inter-denominational competition for financial resources that could weaken the PCRC and undermine its credibility.

\section{Religious Pluralism as a Challenge to Peaceful Coexistence}

The last three decades in Sub-Saharan Africa have been marked by a degree of political liberalization, leading to a boom in non-state organizations including many tied to Christianity and Islam. Some scholars have described the religious component of this evolution in terms of the fragmentation of the religious landscape of Africa. ${ }^{25}$ The multiplication of religious organizations creates new challenges for the postcolonial state as far as the management of religion in the public space is concerned. Furthermore, until recently, Christian missionaries were the dominant religious actor in the public space in most of Sub-Saharan Africa. Today, myriad religious groups of different faiths operate in the public space through politics, social action, or social debates. ${ }^{26}$ This competition for control of the public sphere is a major potential source of conflict.

\section{Forms of Intolevance}

Religion can be used to promote violence or foster peace. African traditional religions are, however, only rarely associated with the former. Over the past 30 years, only a handful of neo-traditional movements have been associated with violence. These include among others the Mai-Mai in the Democratic Republic of the Congo and the Mungiki in Kenya. ${ }^{27}$ There are two main forms of religious intolerance in Sub-Saharan Africa today: attitudinal, which is often conveyed through religious-owned media outlets, propagating negative portrayals of the "other" to increase their following, ${ }^{28}$ or aspects of modernity (especially regarding sexuality and family laws $)^{29}$; and repressive, which is associated with various religiousinspired terror groups, such as the Lord's Resistance Army in Uganda or Boko Haram in Nigeria. ${ }^{30}$ 


\section{Muslim Peacebuilding}

There is a growing awareness of the differences in peacebuilding across different faiths. Côte d'Ivoire and the Central African Republic are two examples of a broader trend in inter-faith initiatives, where Christians and secular leaders take the lead and Muslims play secondary roles. Indeed, lamenting the low visibility of Muslim peacebuilding actors, Mohammed Abu-Nimer and S. Ayse Kadayifci-Orellana write:

The lack of systematic studies that identify and analyze the contributions and shortcomings of Muslim peace-building actors working toward peace in their communities creates the impression that there are no peacebuilding organizations or institutions in the Muslim world. ... Indeed, there are quite a number of nongovernmental organizations, as well as local leaders around the Muslim world, working in their communities to resolve conflicts, build peace, and encourage interfaith dialogue. ${ }^{31}$

Explaining the reasons for their relative obscurity, they add,

Muslim peacebuilding organizations have less experience with formally constituted bodies and stable institutions. For that reason, it is not easy to identify Muslim peace-building NGOs or other institutions similar to those in the West. Nevertheless, in many Muslim societies, NGOs in the modern sense are a new phenomenon, evolving because of contacts with Western/Christian institutions. ${ }^{32}$

Issues around Muslim leadership of peacebuilding initiatives have come into sharper focus due to two interconnected trends: groups identifying with Islam are responsible for more violent attacks than those identifying with Christianity, particularly as it relates to violent extremism; and Muslims comprise a higher number of victims of those attacks than Christians.

Most conflicts generally described as "inter-religious" are rarely primarily about religion. More often, religion is used to articulate perceived political, social, and economic marginalization and the related feelings of frustration. ${ }^{33}$ In Sub-Saharan Africa, recent terrorist attacks notwithstanding, religious intolerance is, almost always, expressed nonviolently. Peaceful coexistence of Africa's religiously diverse communities is the norm, as it has been for generations. This tradition, exploited wisely, can strengthen a culture of peace and social cohesion in Africa. Moreover, trusted religious leaders can be more effective in peacebuilding, 
especially in mediation processes, than secular authorities. "Local religious actors embedded within communities," it is argued, "can often draw on a reservoir of trust not available to secular actors." 34

\section{Key Recommendations}

The politics of inclusion paired with the dispensation of social justice and the respect for human rights remain the cornerstones of any peacebuilding endeavor. In Sub-Saharan Africa, religious leaders and organizations are actively involved in advocacy initiatives for the promotion of social justice and peace. ${ }^{35}$ In some Christian circles, for example, advocacy for the just distribution of natural resources is seen as an integral dimension of peacebuilding. ${ }^{36}$ Muslim traditions have their own indigenous mechanisms for peacebuilding such as sulha (or suluh), and African traditional religions are rich in rituals of reconciliation to restore social harmony. These are resources to build on. More specifically, for the purpose of this chapter, there are three key policy issues that demand the urgent attention of policymakers and religious peacebuilders. ${ }^{37}$

1. Pay move attention to attitudinal intolerance. Policymakers tend to focus on violent forms of religious intolerance. More attention needs to be given to how such violence is seeded, through attitudes promoted in communities, schools and, especially, faith-based media. Funding intolerant attitudes also comes into play at the transnational level, where various global networks are responsible for propagating negative depictions of the "other" at the grassroots level. Thus, efforts to counter hate and build comity cannot be restricted to the elite. ${ }^{38} \mathrm{~A}$ focus on inter-religious and inter-ethnic encounters at the community level will enhance societal resilience and help prevent intolerance from gaining a foothold.

2. Give move assistance to muslim peacebuilding. As radicalized interpretations of religious traditions have gained wider attention through social media, the tendency to equate religion, especially Islam, with heinous acts of terrorism-from Somalia and Kenya through to the Sahel and North Africa-has grown in Africa. Greater effort needs to be invested in the communities that are most affected-both in a perceptual sense, by the misconceptions; and in a practical sense, due to suffering disproportionately from such attacks. "One way to counter these radical and militant voices 
is," some experts argue, "to engage with and strengthen the peacebuilding capacity of Muslim actors that focus on Islamic conflict resolution and Muslim peacemaking traditions." 39 This means concretely supporting the efforts of these actors in spreading the Islamic culture of peace and conflict resolution and "requires understanding specific characteristic of Muslim peace-building actors, their strengths and the challenges they face." 40

3. Promote inter-religious socialization and leadership for peace. Although inter-faith initiatives are mushrooming on the African continent, they need more coordination and networking. In the future national, regional, and continental organizations will need to mainstream inter-religious efforts in a more preventive approach in order to promote tolerance and peaceful coexistence. In most cases, inter-faith initiatives are launched as an ad hoc solution to an escalating conflict. A more sustainable solution would be to establish regional and national offices to coordinate inter-faith efforts for peacebuilding. These efforts should involve continental institutions such as the African Union and sub-regional bodies. Additionally, religious peacebuilders should receive more training in conflict resolution; typically, they know the local terrain much better and are more influential in communities than "outsiders." The professionalization of religious peacebuilders will also make cooperation with secular bodies more effective. It is equally important to educate and sensitize diplomats and international mediators on the place of religion in Africa today, especially in relation to violence and peacemaking. ${ }^{41}$

\section{Notes}

1. Yacob Tesfai, Holy Warriors, Infidels, and Peacemakers in Africa (New York: Palgrave Macmillan, 2010); R. Scott Appleby, "Foreword," in Displacing the State: Religion and Conflict in Neoliberal Africa, James Howard Smith and Rosalind I. J. Hackett (eds.) (Notre Dame, IN: University of Notre Dame Press, 2012), vii-x.

2. Pew Research Center, "The Changing Global Religious Landscape," April 5, 2017, https://www.pewforum.org/2017/04/05/the-changing-glo bal-religious-landscape $/$ ?utm_source=Pew+Research+Center\&utm_cam paign=2a4d274104-EMAIL_CAMPAIGN_2017_04_19\&utm_medium= email\&utm_term=0_3e953b9b70-2a4d274104-399973361. 
3. Henrietta L. Moore and Todd Sanders, "Magical Interpretations and Material Realities: An introduction," in Magical Interpretations, Material Realities Modernity, Witchcraft and the Occult in Postcolonial Africa, Henrietta L. Moore and Todd Sanders (eds.) (London and New York: Routledge, 2001), 12.

4. Barbara Bompani and Maria Frahm-Arp, "Introduction: Development and Politics from Below: New Conceptual Interpretation," in Development and Politics from Below: Exploring Religious Spaces in the African State, Barbara Bompani and Maria Frahm-Arp (eds.) (Houndmills: Basingstoke; New York: Palgrave Macmillan, 2010), 7; see also Stephen Ellis and Gerrie ter Haar, "Religion and Politics in Sub-Saharan Africa," The Journal of Modern African Studies 36, no. 2 (1998): 175-201.

5. Hugh Heclo, "An Introduction to Religion and Public Policy," in Religion Returns to the Public Square: Faith and Policy in America, Hugh Heclo and Wilfred M. McClay (eds.) (Washington, DC: Woodrow Wilson Center Press; Baltimore: The Johns Hopkins University Press, 2003), 18.

6. José Casanova, Public Religions in the Modern World (Chicago, IL and London: Chicago University Press, 1994). See also Religious Actors in the Public Sphere: Means, objectives and effects, Jeffrey Haynes and Anja Hennig (eds.) (London and New York: Routledge, 2011). On Africa in particular, see Bompani and Frahm-Arp, Development and Politics From Below.

7. James Howard Smith, "Religious Dimensions of Conflict and Peace in Neoliberal Africa: An Introduction," in Smith and Hackett, Displacing the State, 1-23.

8. On this see Heclo and McClay, Religion Returns to the Public Square. See also Haynes and Hennig, Religious Actors in the Public Sphere. On Africa in particular, see Barbara Bompani and Maria Frahm-Arp, Development and Politics from Below.

9. Smith and Hackett, Displacing the State.

10. Thomas Banchoff, "Introduction," in Religious Pluralism, Globalization, and World Politics, Thomas Banchoff (ed.) (Oxford: Oxford University Press, 2008), 4.

11. J. Haynes, "Conflict, Conflict Resolution and Peace-Building: The Role of Religion in Mozambique, Nigeria and Cambodia," Commonwealth \& Comparative Politics 47, no. 1 (2009): 63-65. See also Anouilh Pierre, "Sant'Egidio au Mozambique: de la charité à la fabrique de la paix," Revue internationale et stratégique 3, no. 59 (2005): 9-20.

12. See F. E. Boulaga, Les conférences nationales en Afrique: une affaire à suivre (Paris: Karthala, 1993).

13. Isaac Phiri, "Why African Churches Preach Politics: The Case of Zambia," Journal of Church and State, 41, no. 2 (1999): 323-347. 
14. T. Bouta, S. A. Kadayifci-Orellana, and M. Abu-Nimer, Faith-Based Peace-Building: Mapping and Analysis of Christian, Muslim and MultiFaith Actors (The Hague: Clingendael; Washington, DC: Salam Institute for Peace and Justice, 2009), http://www.gsdrc.org/document-library/ faith-based-peace-building-mapping-and-analysis-of-christian-muslim-andmulti-faith-actors/.

15. See Marshal K. et al., "Women in Religious Peacebuilding," USIP Peaceworks, no. 7 (Washington, DC: USIP, 2011): 1-21; Onsati Katherine Kwamboka, Religion, Gender And Peacebuilding in Africa: A Case Study Of Kenya 2007/8 (University of Nairobi, Institute of Diplomacy and International Studies [November 2014]), http://erepository.uonbi.ac. ke/bitstream/handle/11295/75583/Onsati_Religion\%2C\%20gender\% 20 and $\% 20$ peace $\% 20$ building $\% 20$ in $\% 20$ Africa.pdf.pdf? sequence $=3 \&$ isAllo wed $=\mathrm{y}$.

16. UNHCR, et al., Best Practices in Peacebuilding and Non-Violent Conflict Resolution: Some Documented African Women's Peace Initiatives, http://www.peacewomen.org/sites/default/files/unesco_bestpract ices_1998_0.pdf.

17. R. Scott Appleby, "Building Sustainable Peace: The Role of Local and Transnational Religious Actors," in Banchoff, Religious Pluralism, 128. For more illustration of peacebuilding initiative from religious leaders see Peace Weavers: Methodologies of Peace Building in Africa, Elias Omondi Opongo (ed.) (Nairobi: Paulines, 2008); also Catholic Church Leadership in Peace Building in Africa, Elias Omondi Opongo and David Kaulemu (eds.) (Nairobi: Pauline, 2014).

18. Shamsia Ramadhan and Elias Omondi Opongo, "Interreligious Dialogical Action in Kenya: Bridging Faith and Political Participation," in Opongo, Peace Weavers, 28.

19. Marc Gopin, Between Eden and Armageddon, the Future of World Religions, Violence, and Peacemaking (Oxford: Oxford University Press, 2000), 13; R. Scott Appleby, The Ambivalence of the Sacred (Lanham, MD: Rowman \& Littlefiled Publishers, 2002); Appleby, "Foreword," vii-x; Tesfai, Holy Warriors, Infidels, and Peacemakers, 163; Haynes, “Conflict, Conflict Resolution and Peace-Building," 52-75.

20. United Nations Development Program, "Human Development Indicators, Côte d'Ivoire," http://hdr.undp.org/en/countries/profiles/CIV.

21. The daily newspaper Le Patriote, no. 1045, 2003.

22. Sango word for "coalition." Sango is the other major language of Central African Republic besides French.

23. Meaning “anti-cutlass” in Sango.

24. Plateforme des Confessions Religieuses de Centrafrique (PCRC), http:// www.pcrc-rca.org. 
25. Maud Lasseur and Cedric Mayrargue, "Le Religieux dans la Pluralisation Contemporaine: Eclatement et Concurrence," Politique Africaine 123 (2011): 5-25.

26. Muriel Gomez-Perez (ed.), L'Islam Politique au Sud du Sahara (Paris: Karthala, 2005).

27. Grace Nyatugah Wamue-Ngare, "The Mungiki Movement: A Source of Religio-Political Conflict in Kenya," in Smith and Hackett, Displacing the State, 108; On the Mai-Mai, see Koen Vlassenroot, "Magic as Identity Maker: Conflict and Militia Formation in Eastern Congo," in Smith and Hackett, Displacing the State, 113-135.

28. Asonzeh F.-K. Ukah, "Mediating Armageddon: Popular Christian Video Films as a Source of Conflict in Nigeria", in Smith and Hackett, Displacing the State, 209-239; see also Rosalind I. J. Hackett, "Devil Bustin' Satellites: How Media Liberalization in Africa Generates Religious Intolerance and Conflict," in Smith and Hackett, Displacing the State, 163-208.

29. For more on this, see Abasi Kiyimba, “The Domestic Relations Bill' and Inter-Religious Conflict in Uganda: A Muslim Reading of Personal Law and Religious Pluralism in a Postcolonial Society," in Smith and Hackett, Displacing the State, 240-280.

30. See T. Howard, "Failed States and the Spread of Terrorism in SubSaharan Africa," Studies in Conflict \& Terrorism 33, no. 11 (2010): 960-988, https://doi.org/10.1080/1057610x.2010.51469; Mwangi O. Gakuo Mwangi, "State Collapse, Al-Shabaab, Islamism, and Legitimacy in Somalia," Politics, Religion \& Ideology 13, no. 4 (2012): 513527, https://doi.org/10.1080/21567689.2012.725659; Boko Haram: Islamism, Politics, Security and the State in Nigeria, Marc-Antoine Pérouse de Montclos (ed.) (Leiden: African Studies Center, 2014); M.-A. Pérouse de Montclos, Boko Haram et le terrorisme islamiste an Nigeria: Insurrection religieuse, contestation politique ou protestation sociale? Questions de recherche, Centre d'études et de recherches internationals, June 6, 2012, https://ssrn.com/abstract=2282542; J. C. Amble and Alexander Meleagrou-Hitchens, "Jihadist Radicalization in East Africa: Two Case Studies," Studies in Conflict of Terrorism 37, no. 6 (2014), https://doi. org/10.1080/1057610x.2014.893406; Adekundo Adesoji, "The Boko Haram Uprising and Islamic Revivalism in Nigeria," Africa Spectrum 45, no. 2 (2010): 95-108.

31. Mohammed Abu-Nimer and S. Ayse Kadayifci-Orellana, "Muslim PeaceBuilding Actors in Africa and the Balkan Context: Challenges and Needs," Peace \& Change 33, no. 4 (2008): 551.

32. Abu-Nimer and Kadayifci-Orellana, "Muslim Peace-Building Actors," 564. 
33. As Thomas Banchoff puts it, "Religion is never the sole cause of violence. It intersects in explosive ways with territorial disputes; unstable and oppressive institutions; economic and social inequalities; and ethnic, cultural, and linguistic divisions." For this see Banchoff, "Introduction," 3.

34. Banchoff, "Introduction," 22.

35. Opongo, Catholic Church Leadership in Peace Building in Africa.

36. Antoine Berilengar, "Advocacy for Just Distribution of Oil Revenues: The Case of Chad," in Opongo, Peace Weavers, 86-94; Ferdinand Muhigirwa, "Review and Evaluation Process of Mining Contracts in the Democratic Republic of Congo," in Opongo, Peace Weavers, 95-102.

37. Ludovic Lado, "Addressing Religious Violence in Sub-Saharan Africa," Woodrow Wilson International Center for Scholars, September 1, 2014, https://www.wilsoncenter.org/publication/addressing-religious-vio lence-sub-saharan-africa.

38. Gopin, Between Eden and Armageddon, 35.

39. Abu-Nimer and Kadayifci-Orellana, "Muslim Peace-Building Actors," 551 .

40. Ibid., 563.

41. Gopin, Between Eden and Armageddon, 35.

Open Access This chapter is licensed under the terms of the Creative Commons Attribution 4.0 International License (http://creativecommons.org/licenses/ by $/ 4.0 /$ ), which permits use, sharing, adaptation, distribution and reproduction in any medium or format, as long as you give appropriate credit to the original author(s) and the source, provide a link to the Creative Commons license and indicate if changes were made.

The images or other third party material in this chapter are included in the chapter's Creative Commons license, unless indicated otherwise in a credit line to the material. If material is not included in the chapter's Creative Commons license and your intended use is not permitted by statutory regulation or exceeds the permitted use, you will need to obtain permission directly from the copyright holder.

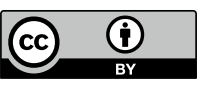

